Ekonomia - Wroclaw Economic Review 24/2 (2018)

Acta Universitatis Wratislaviensis

No 3858

DOI: 10.19195/2084-4093.24.2.6

Agnieszka Parkitna

ORCID: 0000-0002-8546-399X

Politechnika Wrocławska

Katedra Infrastruktury Zarządzania

agnieszka.parkitna@pwr.edu.pl

Arkadiusz Górski

ORCID: 0000-0003-3595-9820

Politechnika Wrocławska

Katedra Systemów Zarządzania

arkadiusz.gorski@pwr.edu.pl

\title{
Problematyka konfliktu interesów w funkcjonowaniu rynku kapitałowego
}

Artykuł nadesłany: 12 listopada 2017 r.; artykuł zaakceptowany: 20 kwietnia 2018 r.

JEL Classification: G14, G10, G24

Keywords: conflict of interest, capital market, stock investment risk

Abstract

Problems of conflicts of interest in the functioning of the capital market

The study refers to the occurrence of conflicts of interest on the capital market, which negatively affects the functioning of the capital market, limits its development potential, and may even affect the outflow of investors, particularly those providing liquidity in the market. Today, the social responsibility of business entities becomes something important. It is a specific determinant of the company's image and the basis of its operation. Word = Institution "brokerage house" should be associated with competence, honesty, or righteousness resulting from observance of the law and ethics principles of conducted business.

The existence of a set of regulations (the Code of Good Practice for Brokerage Houses, the Act on Counteracting Unfair Market Practices) relating to the functioning of brokerage houses, there are situations in business practice that are not used to develop a capital market, based on a conflict of interest.

Brokerage firms are obliged, on the one hand, to: sell shares and, on the other hand, recommend buying them. "Manipulation on the market" would mean entering into transactions that give false, misleading signals about supply, demand, and prices of equity instruments. To avoid conflicts 
of interest, there are special procedures in brokerage offices that prevent co-operation between competing departments: chinese walls.

Each office additionally has rules governing the flow and control of confidential information. Such information may not be available, for example, between primary and secondary market forces, between sales departments and analysis departments.

The indicated issues were brought together, focusing on the possible consequences of conflicts of interest. It emphasizes the difficulty of bringing justice through the necessity of showing the causal link between the conflict of interest and the possible loss of the investor. Then solutions were identified to protect against the negative aspects of the conflict of interest, and the proposals were presented in their conclusions.

\section{Wstęp}

Sprawne funkcjonowanie rynku kapitałowego w Polsce i jego rozwój wymagają przejrzystych reguł nim rządzących. Istotnym aspektem wywierającym wpływ na funkcjonowanie polskiego rynku kapitałowego jest problematyka konfliktu interesów. Klienci instytucji finansowych działających na rodzimym rynku kapitałowym powinni być chronieni przed negatywnym wpływem tego zjawiska, które może wpłynąć na poniesienie przez nich znaczących strat z inwestycji kapitałowych. Natomiast w odniesieniu do funkcjonowania samego rynku kapitałowego może ono powodować odpływ kapitału inwestorów na rynki zewnętrzne i w konsekwencji zmniejszenie zainteresowania inwestycjami kapitałowymi.

Ochrona przed konfliktem interesów na rynku kapitałowym przybiera różne formy, zarówno prawne, jak i instytucjonalne. $\mathrm{Z}$ reguły jednak ochrona uczestników rynku kapitałowego sprowadza się do zapisów umownych w umowach pomiędzy inwestorami a pośrednikami wskazujących na zakaz przeprowadzania transakcji prowadzących do konfliktu interesów i obowiązku uzyskania zgody klienta-inwestora na tego typu transakcje. Niestety stosowane rozwiązania nie stanowią dla odbiorców usług na rynku kapitałowym praktycznie żadnej ochrony. Naruszenie zapisów umownych dotyczących konfliktu interesu, przykładowo w umowie doradztwa inwestycyjnego czy też zarządzania portfelem aktywów pomiędzy klientem-inwestorem a domem maklerskim bądź doradcą inwestycyjnym, w praktyce nie pozwala na skuteczne dochodzenie konsekwencji prawnych. W wypadku wykrycia przez inwestora podejmowanych w stosunku do niego działań pośrednika o znamionach konfliktu interesów może on zaprotestować i zwrócić się o zaprzestanie tego typu praktyk. Jednakże za ewentualne straty poniesione na transakcjach obarczonych konfliktem interesów bardzo trudno inwestorom uzyskać zadośćuczynienie w postaci rekompensat od instytucji finansowej. Ewidentne naruszenie zapisów umownych łączących strony nie powoduje bowiem, że instytucja finansowa będzie odpowiadać za ewentualne straty na transakcjach związanych przykładowo z konfliktem interesów. Klient w takiej sytuacji musi zatem kierować sprawę na drogę sądową, aby uzyskać ewentualne odszkodowanie. 
W polskim prawodawstwie w takich sytuacjach bada się związek przyczynowo-skutkowy, co oznacza, że sąd musi sprawdzić, czy konflikt interesów faktycznie miał wpływ na straty poniesione przez klienta. W przypadku zarządzania aktywami klienta przez dom maklerski lub inną firmę uprawnioną do doradztwa na rynku kapitałowym przy znacznej dociekliwości możliwe jest na wskazanie konfliktu interesów, jednakże bardzo trudne jest wykazanie związku pomiędzy naruszeniem zapisów w zakresie konfliktu interesów a ewentualną stratą poniesioną przez klienta.

Podmiot doradzający zawsze będzie thumaczył się ryzykiem inwestycyjnym, które przecież nikomu nie gwarantuje dodatniej stopy zwrotu na rynku kapitałowym, i będzie negował związek przyczynowo-skutkowy w tym zakresie. $Z$ tych względów właściwe wydaje się poszukiwanie rozwiązań chroniących klientów instytucji finansowych, w szczególności w zakresie konfliktu interesów. Nieuprawnione przeprowadzanie transakcji obarczonych konfliktem interesów powinno być obciążone obowiązkowymi karami umownymi lub być uznawane przez prawodawstwo za transakcje, za które całkowicie odpowiadać będzie strona naruszająca zapisy umowne. Nie powinno być sytuacji, w których klient musi wykazać wpływ konfliktu na ewentualną stratę. Wobec tego zasadna jest dyskusja nad zmianami w zakresie rozstrzygania sporów związanych z problemem konfliktu interesów.

\section{Teoretyczny aspekt badań}

Problematyka efektywności rynku kapitałowego jest zagadnieniem często poruszanym przez teoretyków finansów. Jeśli rynki kapitałowe są efektywne, to akcje i inne instrumenty finansowe są wyceniane prawidłowo oraz odpowiednio odzwierciedlają wartość aktywów im odpowiadających. Opozycyjna koncepcja głosi, że wycena instrumentów finansowych zawiera systematyczne i wykrywalne błędy, a inwestor potrafiący zaobserwować te odchylenia może osiągnąc ponadprzeciętne zyski.

W dzisiejszych czasach Internet pełen jest źródeł konkurencyjnej analizy i technicznych ekspertyz. Pozostaje jednak wciąż żywa kluczowa zasada inwestorów, która powinna opierać się na [...] zdobyciu prawdziwej i podstawowej wiedzy na temat spółek, które są celem inwestycji ${ }^{1}$.

Efektywność rynków kapitałowych w sensie informacyjnym jest także powiązana z efektywnością alokacyjną tych rynków. Rynek kapitałowy stanowi miejsce, które odzwierciedla opinie jego uczestników na temat ich przyszłości. Jeśli ceny aktywów finansowych ukazują te oczekiwania, jeśli rynek jest efektywny, to stanowią one wartościowy sygnał dla menedżerów dążących do maksymalizacji

${ }^{1}$ G. Gillder, Afera z wykorzystaniem informacji poufnych, [w:] Reguty gietdy, red. J.F. Mauldin, Gliwice 2006, s. 302. 
wartości swojej firmy. Jednocześnie jeśli ceny aktywów zawierają istotne systematyczne błędy, to oparte na tych informacjach decyzje menedżerów, a także inwestorów narażone są na znaczące zakłócenia ${ }^{2}$. Badania Jeffreya Jaffe'ego ${ }^{3}$ wskazały możliwość osiągnięcia istotnych zysków przy wykorzystaniu informacji poufnej. Podobne analizy zostały przeprowadzone przez zespół Irwina Frienda ${ }^{4}$ oraz Bradforda Cornella i Richarda Rolla ${ }^{5}$. Potwierdzające badanie efektywności związanej z dostępem do informacji zostało również zrealizowane dla polskiego rynku kapitałowego przez grupę naukowców: Jana Czekaja, Mirosława Wosia i Janusza Żarnowskiego ${ }^{6}$.

Wobec tego kluczową rolę w funkcjonowaniu rynku kapitałowego odgrywają podmioty pośredniczące $\mathrm{w}$ obrocie instrumentami finansowymi, w szczególności domy maklerskie, które dysponują ponadprzeciętnymi informacjami z rynku, często również poufnymi. Specyfiką ich funkcjonowania jest ścieranie się interesów dwóch grup interesariuszy, pomiędzy którymi występuje naturalna sprzeczność. Domy maklerskie, z jednej strony, zajmują się bowiem oferowaniem papierów wartościowych, z drugiej zaś, rekomendują ich kupno.

Domy maklerskie i podmioty z grupy kapitałowej, do której należy dany dom maklerski, świadczą szereg usług na rynku finansowym dla zróżnicowanej grupy podmiotów, w szczególności mogły lub mogą w odniesieniu do instrumentów finansowych, będących przedmiotem zleceń klienta, realizować zlecenia przeciwstawne, wykonywać funkcje animatora, oferować instrumenty finansowe, nabywać lub zbywać instrumenty na własny lub cudzy rachunek oraz mogły lub mogą dokonywać transakcji na tych instrumentach, a także świadczyć usługi zarządzania instrumentami finansowymi, świadczyć usługi brokerskie oraz usługi w zakresie bankowości inwestycyjnej na rzecz emitentów instrumentów finansowych, których instrumenty finansowe są lub mogą być przedmiotem inwestycji klienta, mogą działać jako subemitent usługowy lub subemitent inwestycyjny w ramach ofert instrumentów finansowych, a także w transakcjach fuzji i przejęć i innych czynnościach dotyczących emitentów instrumentów finansowych, w odniesieniu do instrumentu finansowego, będącego przedmiotem zainteresowania Klienta, być emitentami instrumentów finansowych lub być powiązane z emitentami instrumentów finansowych oraz otrzymywać $\mathrm{z}$ tego tytułu wynagrodzenie, prowizje, a także realizować zyski

Przybliżone zadania domu maklerskiego i sytuacja, w jakiej się znajduje, mogą doprowadzić do wygenerowania strat dla jednej ze stron transakcji. Szcze-

2 R. Ślepaczuk, Anomalie rynku kapitałowego w świetle hipotezy efektywności rynku, ,e-Finanse: Finansowy Kwartalnik Internetowy” 2006, nr 1, s. 1.

3 J. Jaffe, Special information and insider trading, ,Journal of Business” 1974, nr 47, s. 410-415.

${ }^{4}$ I. Friend et al., A Study of Mutual Funds, Washington 1962.

5 R. Cornell, R. Roll, Strategies for pairwise competitions in market and organizations, „Bell Journal of Economics" 1981, nr 12 (1), s. 205-211.

6 J. Czekaj, M. Woś, J. Żarnowski, Efektywność giełdowego rynku akcji w Polsce, Warszawa 2001.

7 Standard ogólnych zasad zarządzania konfliktem interesów udostępniany klientom przed zawarciem umowy — Rozporządzenie Ministra Finansów z dnia 30 maja 2018 roku w sprawie trybu i warunków postępowania firm inwestycyjnych, banków, o których mowa w art. 70 ust. 2 ustawy o obrocie instrumentami finansowymi, oraz banków powierniczych, Dz.U. z 2018 r. poz. 1112, § 10, ust. 2, pkt 10 . 
gólnie ewidentnym przypadkiem może być sytuacja, gdy dom maklerski, obsługując emisję akcji na rynku pierwotnym, uzyskuje wynagrodzenie będące pochodną sukcesu przeprowadzanej emisji, a jednocześnie, aby doprowadzić do sukcesu emisję, za którą jest odpowiedzialny, oferuje te instrumenty swoim klientom będącym inwestorami, rekomendując ich zakup, a pośrednicząc w tej transakcji, otrzymuje również wynagrodzenie.

Dążenie do zakończenia z sukcesem emisji akcji rodzi obawy, czy w sposób obiektywny doradza się potencjalnym nabywcom oferowanych instrumentów finansowych. Czy przedstawiane im propozycje są rzeczywiście w danej sytuacji najbardziej korzystne dla inwestorów? Dualność położenia domu maklerskiego może doprowadzić inwestorów do wniosku, że pośrednik na rynku kapitałowym świadomie próbuje wprowadzić ich w błąd, oferując i zachęcając do kupna instrumentów, od których sprzedaży otrzymuje drugie wynagrodzenie — prowizję nie tylko od inwestora, lecz także od emitenta.

Regulacje związane z funkcjonowaniem domów maklerskich mają zagwarantować właściwe funkcjonowanie rynku kapitałowego z zachowaniem interesów wszystkich uczestników rynku. Kodeks dobrej praktyki domów maklerskich w $\S 3$ pkt 2 obliguje

pośredników w prowadzonej działalności na rzecz osób trzecich zachować należytą staranność, [a w] § 4 [...] kierować się dbałością o bezpieczeństwo rynku, w szczególności wprowadzając wewnętrzne zasady monitorowania transakcji oraz przeciwdziałania praktykom manipulacji instrumentami finansowymi ${ }^{8}$.

Jednakże czy mało rygorystyczne zapisy przywołanego kodeksu są w stanie zmusić pośredników, aby byli w stanie oprzeć się pokusie podwójnego zarobku, aby zachowywali należytą staranność w obsłudze inwestorów, aby podejmowali decyzje w ich imieniu lub doradzali im bez obciążającego ich konfliktu interesów, co może znacząco zsubiektywizować propozycję inwestycyjną?

Występowanie konfliktu interesów jest niejako wpisane w funkcjonowanie rynku kapitałowego, a jego pojawienie się nie jest równoznaczne z negatywnym efektem wyników inwestycyjnych na rynku kapitałowym. Odnosząc się do przywołanego przykładu domu maklerskiego obsługującego emisję akcji, z pewnością można założyć, że będzie on bardzo dobrze zorientowany w sytuacji spółki będzie miał bardzo dobrze rozeznane wyniki spółki, a także będzie mógł rzetelnie ocenić przedstawiane prognozy. Można wręcz wyjść z założenia, że jego wiedza o danej spółce będzie najpełniejsza i prawdopodobnie pozwalająca na podejmowanie najwłaściwszych decyzji. Przywołane argumenty skłaniałyby zgoła do inwestowania przy udziale pośredników dysponujących tak znaczną wiedzą o spółce, którą należy określić jako powiązaną z pośrednikiem, co powinno być uznawane za gwarancję powodzenia podejmowanych decyzji inwestycyjnych.

8 Izba Domów Maklerskich, Kodeks dobrej praktyki domów maklerskich, https://idm.com.pl/ images/regulacje/Kodeks_dobrej_praktyki_domow_maklerskich.pdf (dostęp: 2.09.2017). 
Prowadzone badania nie potwierdzają jednak tak optymistycznej perspektywy dla inwestora funkcjonującego na rynku kapitałowym. Występujący w przedstawianej sytuacji konflikt interesów może niestety wypaczać oczekiwane od domów maklerskich czy innych instytucji rynku kapitałowego staranność i obiektywizm.

Decyzje inwestycyjne na giełdach papierów wartościowych uwarunkowane są wieloma czynnikami. Wśród nich istotne znaczenie mają uwarunkowania psychologiczne, które stanowią obszar badań w zakresie tak zwanych finansów behawioralnych ${ }^{9}$. Pokusa nadużyć powstaje w momencie zmiany statusu uczestnika procesu decyzyjnego, gdy zdaje on sobie sprawę z przewagi informacyjnej nad drugą stroną ${ }^{10}$, a domy maklerskie czy też inni pośrednicy na rynku kapitałowym taką przewagę mają, a ryzyko jej wykorzystania jest bardzo duże.

Konflikt interesów może znacząco wypaczać wyniki inwestycyjne i wręcz powodować znaczące straty po stronie inwestorów, w szczególności w okresie znacznych wahań na rynku kapitałowym. W wypadku rosnącego rynku praktycznie wszystkie strony transakcji na rynku kapitałowym są „wygrane” — negatywnych stron konfliktu interesu można nie dostrzec. Pośrednik, przykładowo w postaci domu maklerskiego, w sytuacji konfliktu interesów uzyskuje podwójne wynagrodzenie, zarówno od emitenta, jak i od inwestora, rynek rośnie, każda ze stron zyskuje i jest zadowolona. Jednakże w sytuacji rynku trudnego pośrednik może zacząć przedkładać własne korzyści nad korzyści małych inwestorów, którym doradza lub w których imieniu dokonuje transakcji na rynku kapitałowym. Należałoby się zastanowić, czy doradztwo domu maklerskiego (dalej również jako DM) dla inwestora indywidualnego jest zobowiązaniem rezultatu czy starannego działania? Ma to niebagatelne znaczenie przy ocenie, czy DM należycie wypełnił świadczenie wynikające z umowy. Zobowiązanie rezultatu obarcza DM powinnością uzyskania określonego od początku, sprecyzowanego wyniku, podczas gdy w zobowiązaniu starannego działania wymaga zachowania należytej staranności w zmierzaniu do wybranego celu ${ }^{11}$. W umowie z DM znajduje się bowiem zapis o prowizji od uzyskanych zysków, a DM zobowiązuje się do inwestowania zgodnie ze strategią, która jest integralną częścią, przyjmującą postać załącznika, takiej umowy. Taki rodzaj zapisu jest zobowiązaniem należytej staranności w działaniu DM na korzyść klienta umowy, którym jest inwestor. W momencie gdy DM osiąga ponadprzeciętną stratę, z punktu widzenia inwestorów łamie zasadę zobowiązania należytej staranności. A zatem w wypadku niewyko-

9 M. Wasilewski, M. Juszczyk, Znaczenie czynników behawioralnych w podejmowaniu decyzji inwestycyjnych na rynku kapitałowym, „Zeszyty Naukowe Szkoły Głównej Gospodarstwa Wiejskiego. Ekonomika i Organizacja Gospodarki Żywnościowej” 2016, nr 113, s. 173-183.

$10 \mathrm{~J}$. Cohen et al., The effects of perceived fairness on opportunistic behavior, „Contemporary Accounting Research" 2007, nr 24 (4), s. 1119-1138.

11 T. Dybowski, System prawa cywilnego, [w:] System prawa cywilnego, t. 3, cz. 1. Prawo zobowiązań - częśś ogólna, red. Z. Radwański, Wrocław 1981, s. 45, 81. 
nania zobowiązania powstaje odpowiedzialność odszkodowawcza ${ }^{12}$ DM zgodnie z zasadami Kodeksu cywilnego (art. 471 n.) $)^{13}$.

Na podstawie prowadzonych badań literaturowych oraz analizy kilkudziesięciu inwestycji przeprowadzonych w imieniu inwestora przez pośrednika, a także własnych rozważań i dociekań nad skutkami uwikłania w konflikt interesu wskazano możliwość wystąpienia następujących zachowań ze strony pośredników, które mogą negatywnie wpłynąć na wyniki inwestycyjne inwestorów:

- preferencyjne dokonywanie transakcji w walory powiązane;

— brak obiektywizmu w ocenie walorów powiązanych;

- manipulacje rynkiem - rekomendowanie klientom walorów powiązanych, a nawet wykorzystywanie ich poprzez środki z zarządzanych portfeli inwestycyjnych do zapisu na upubliczniane powiązane walory, co zwiększa zainteresowanie nimi na rynku kapitałowym, lub przedstawianie nieobiektywnych rekomendacji czy wręcz celowy brak wyjścia w imieniu inwestorów z inwestycji we wprowadzone na rynek kapitałowy walory, aby uzyskać efekt niepogłębienia ewentualnego trendu spadkowego;

— rutyna - makler, doradca ślepo wierzy w nieomylność opracowanych i zaakceptowanych prognoz dla powiązanej spółki.

Zidentyfikowane i wyliczone skutki występowania w działalności pośredników konfliktu interesów należy uznać za jak najbardziej prawdopodobne. Dlatego też konieczne jest analizowanie obowiązujących regulacji i ich ewentualne modyfikowanie, co powinno ograniczyć odnotowywanie negatywnych skutków konfliktu interesów i tym samym chronić inwestorów, zapewniając większą przejrzystość na rynku kapitałowym.

\section{Rozwiązania zabezpieczające przed negatywnymi skutkami konfliktu interesów}

Obserwacja rynku finansowego Unii Europejskiej pozwala stwierdzić, że w ciągu ostatnich kilkudziesięciu lat zaszły na nim istotne zmiany. Źródłem obserwowanych zmian są, z jednej strony, liberalizacja finansowa, globalizacja i postęp technologiczny, z drugiej natomiast — działania w zakresie kształtowania rynku finansowego podejmowane na szczeblu UE. Unia Europejska dąży do stworzenia jednolitego rynku finansowego obejmującego wszystkie kraje członkowskie ${ }^{14}$.

12 Kodeks cywilny. Komentarz, red. J. Gudowski, t. 4-5. Zobowiazania. Czesść szczegółowa, Warszawa 2017, s. 258-488.

13 W. Góralczyk jun., Tajemnica bankowa, [w:] Prawo informacji, prawo do informowania, red. W. Góralczyk jun., Warszawa 2006, s. 241.

${ }^{14}$ M. Mikita, Rynek finansowy Unii Europejskiej - wyzwania, „Studia BAS” 2012, nr 3 (31), s. $29-30$. 
Jego istotą jest zapewnienie swobody przepływu kapitału w krajach członkowskich, a także swobody świadczenia usług finansowych w obrębie tych państw ${ }^{15}$.

W sytuacji przestrzegania prawa i zasad etyki prowadzonej działalności przez pośredników na rynku kapitałowym, a w szczególności prowadzenia działalności w sposób przejrzysty, umożliwiający zwiększenie bezpieczeństwa pozostałych uczestników rynku, w sposób kompetentny, uczciwy i prawy, z pewnością konflikt interesów nie stanowiłby problemu. Sprzeczność interesów występująca między różnymi uczestnikami rynku kapitałowego wymusiła wprowadzanie i stosowanie wielu rozwiązań pozwalających na regulację rynku kapitałowego, które w zamyśle mają dbać o interes różnych uczestników rynku kapitałowego, w tym tych najsłabszych, czyli inwestorów indywidualnych.

Okresem szczególnej intensyfikacji prac integracyjnych w ramach rynku finansowego były lata 1999-2004. Opracowano wówczas liczne dokumenty (dyrektywy, rozporządzenia, rekomendacje) odnośnie do różnych zagadnień związanych z działaniem rynku finansowego. Wśród nich znalazły się między innymi:

- dyrektywa dotycząca obrotu instrumentami finansowymi na rynku europejskim ${ }^{16}$ (Markets in Financial Instrument Directive - MiFID),

- dyrektywa dotycząca standaryzacji informacji zawartych w prospektach emisyjnych (Prospectus Directive),

- dyrektywa dotycząca działania funduszy inwestycyjnych na rynku UE (Undertakings for Collective Investments in Transferable Securities II - UCITS II),

- dyrektywa określająca zasady, jakie muszą być przestrzegane przez uczestników rynku papierów wartościowych (Settlemnet Finality and the Financial Collateral Directives),

— dyrektywa określająca wymogi kapitałowe dla banków (Capital Requirements Directive - CRD).

Prace nad ujednoliceniem pewnych rozwiązań w zakresie działania rynku finansowego były prowadzone w ramach programu o nazwie „Financial Services Action Plan” (FSAP, „Plan działania w zakresie usług finansowych”). W ramach tego programu UE stworzyła podstawy prawne funkcjonowania jednolitego rynku finansowego. Podjęła również próbę harmonizacji krajowych rynków finansowych poprzez ujednolicenie przepisów regulujących ich funkcjonowanie ${ }^{17}$.

Zgodnie z przepisami MiFID ${ }^{18}$ każdy podmiot oferujący usługi inwestycyjne zobowiązany jest:

15 Governor Draghi's speech at the Integrated and Stable Financial Markets Conference, 2 maja 2011, Bruksela, http://ec.europa.eu (dostęp: 1.07.2011).

16 Dyrektywa 2004/39/WE Parlamentu Europejskiego i Rady z dnia 21 kwietnia 2004 roku w sprawie rynków instrumentów finansowych zmieniająca dyrektywę Rady 85/611/EWG i 93/6/ EWG i dyrektywę 2000/12/WE Parlamentu Europejskiego i Rady oraz uchylająca dyrektywę Rady 93/22/EWG, Dz.U. UE L145 z 30.04.2004, http://eur-lex.europa.eu/legal-content/PL/TXT/?uri=CE LEX:02004L0039-20110104 (dostęp: 2.09.2017); dalej jako: dyrektywa MiFID.

17 M. Mikita, op. cit., s. 33.

18 Dyrektywa MiFID, s. 1. 
— postępować uczciwie, sprawiedliwie, profesjonalnie w najlepszym interesie klienta;

— dostarczać właściwych i kompletnych informacji rzetelnych, jednoznacznych i niewprowadzających w błąd;

- dostarczać klientom usługi dostosowane do ich indywidualnych potrzeb inwestycyjnych.

Dyrektywa MiFID w sprawie rynków instrumentów finansowych od listopada 2007 roku obowiązuje w całej Unii Europejskiej. Jest to fundament unijnego rozporządzenia dotyczącego rynków finansowych mający na celu poprawę konkurencyjności rynków finansowych UE poprzez utworzenie jednolitego rynku usług i działalności inwestycyjnej oraz zapewnienie wysokiego stopnia ochrony inwestorów instrumentów finansowych. Dyrektywa wprowadza wymogi regulacyjne w celu uniknięcia nadużyć na rynku oraz zapewnienia przejrzystości handlowej w odniesieniu do akcji.

W dniu 20 października 2011 roku Komisja Europejska przyjęła wniosek ustawodawczy dotyczący zmiany MiFID, który przyjęto w formie zmienionej dyrektywy i nowego rozporządzenia. Unia Europejska przyjęła dyrektywę MiFID, aby umocnić ramy prawne dotyczące zarówno usług inwestycyjnych, jak i rynków regulowanych, dążąc do osiągnięcia następujących celów:

- ochrona inwestorów;

— integralność rynku dzięki przyjęciu zharmonizowanych wymogów prawnych odnośnie do prowadzenia działalności przez autoryzowanych pośredników;

- wspieranie uczciwości, przejrzystości, a także efektywności oraz integracji rynków finansowych.

W Polsce dyrektywa MiFID całkowicie zaimplementowana została dopiero 21 października 2009 roku, kiedy weszła w życie Ustawa z dnia 4 września 2008 roku o zmianie ustawy o obrocie instrumentami finansowymi oraz niektórych innych ustaw $^{19}$.

W celu ujednolicenia postępowania firm inwestycyjnych europejska dyrektywa MiFID wymaga, aby:

1) „wszelkie informacje, w tym handlowe, kierowane przez firmę inwestycyjną do klientów lub potencjalnych klientów były rzetelne, niebudzące wątpliwości i niewprowadzające w błąd, a informacje handlowe wyraźnie oznaczone, jako mający taki charakter (art. 19 ust. 2);

2) firma inwestycyjna przekazywała klientom lub potencjalnym klientom kompleksowe informacje dotyczące:

a) tej firmy oraz świadczonych przez nią usług;

b) instrumentów finansowych oraz proponowanych strategii inwestycyjnych, co powinno obejmować stosowne wytyczne oraz ostrzeżenia o ryzyku związanym z inwestycjami w dane instrumenty lub odnoszącym się do poszczególnych strategii;

c) podmiotów realizujących zlecenia oraz

d) kosztów i opłat. Przy czym informacje powinny umożliwić klientom lub potencjalnym klientom zrozumienie charakteru oraz ryzyka związanych z usługą inwestycyjną oraz określonym

19 Dz.U. z 2009 r. Nr 165, poz. 1316. 
rodzajem oferowanego instrumentu finansowego, aby mogli podjąć świadome decyzje inwestycyjne. Informacje te należy przekazywać w ujednoliconym formacie (art. 19 ust. 3);

3) firma inwestycyjna świadcząc usługi doradztwa inwestycyjnego lub zarządzania portfelem instrumentów finansowych uzyskiwała niezbędne informacje dotyczące wiedzy i doświadczenia klientów lub potencjalnych klientów w dziedzinie inwestycji odpowiedniej do określonego rodzaju produktu czy usługi, jego sytuacji finansowej oraz celów inwestycyjnych, tak, aby mogła polecić klientowi lub potencjalnemu klientowi odpowiednie dla niego usługi inwestycyjne i instrumenty finansowe, tzw. zasada know your customer oraz powiązany z nią tzw. obowiązek eksploracyjny (art. 19 ust. 4);

4) firma inwestycyjna świadcząc inne usługi inwestycyjne niż doradztwa inwestycyjnego lub zarządzania portfelem zwróciła się do klienta lub potencjalnego klienta z prośbą o przekazanie informacji dotyczących jego wiedzy i doświadczenia w zakresie inwestycji, odpowiedniej do określonego rodzaju oferowanego lub wymaganego produktu lub usługi, tak, aby mogła dokonać oceny, czy przewidziana usługa inwestycyjna lub produkt są dla niego odpowiednie. Przepis przewiduje jednak wyjątki łagodzące wymogi, zwłaszcza dla usług wyłącznego wykonywania zleceń (tzw. execution only) (art. 19 ust. 5);

5) firma inwestycyjna prowadziła rejestr obejmujący dokumentację uzgodnioną między nią a klientem, określającą prawa i obowiązki stron, a także pozostałe warunki, na których firma świadczy usługi na rzecz klienta (art. 19 ust. 7);

6) firma inwestycyjna przekazywała klientowi sprawozdania odnośnie świadczonych usług, obejmujących w miarę potrzeb informacje na temat kosztów związanych z transakcjami i usługami wykonywanymi w jego imieniu (art. 19 ust. 8) 20.

Rozwiązania MiFID stosunkowo szybko zostały uznane za niewystarczające. W efekcie po intensywnych debatach Parlament Europejski i Rada przyjęły kolejne dyrektywy w sprawie rynków instrumentów finansowych, zwane powszechnie MiFID II ${ }^{21}$ oraz MiFIR ${ }^{22}$ (opublikowane w Dzienniku Urzędowym Unii Europejskiej w dniu 12 czerwca 2014 roku). Nowe zasady mają na celu uwzględnienie zmian w otoczeniu zewnętrznym (prawnym i finansowym), w szczególności w świetle kryzysu finansowego, poprawiając w ten sposób funkcjonowanie rynków finansowych, zwiększając ich efektywność i przejrzystość. MiFID II/MiFIR miały początkowo zacząć funkcjonować z dniem 3 stycznia 2017 roku. Ze względu jednak na wyzwania związane z wdrażaniem nowych przepisów Komisja Europejska w lutym 2016 roku przedstawiła wniosek o opóźnienie rozpoczęcia ich stosowania o rok. Niniejsza poprawka została przyjęta przez Parlament Europejski i Radę w dniu 23 czerwca 2016 roku i w efekcie MiFID II/MiFIR obowiązują od dnia 30 stycznia 2018 roku ${ }^{23}$. W zakresie rozpatrywanej problematyki dyrektywa ta wprowadza tak zwany model „niezależnego” do-radztwa, który wymusza

20 Art. 19 ust. 1 dyrektywy MiFID.

21 Dyrektywa Parlamentu Europejskiego i Rady 2014/65/UE z dnia 15 maja 2014 roku w sprawie rynków instrumentów finansowych oraz zmieniająca dyrektywę 2002/92/WE i dyrektywę 2011/61/UE, Dz.Urz. UE L 173/349 z 12.06.2014.

22 Rozporządzenie Parlamentu Europejskiego i Rady (UE) nr 600/2014 z dnia 15 maja 2014 roku w sprawie rynków instrumentów finansowych oraz zmieniające rozporządzenie (EU) $\mathrm{nr}$ 648/2012, Dz.Urz. UE OJ L 173 z 12.06.2014, s. 84-148.

23 European Securities and Markets Authority, MiFID II, https://www.esma.europa.eu/policyrules/mifid-ii-and-mifir\#title-paragrah-2 (dostęp: 26.09.2017). 
wprowadzenie rozwiązań zapobiegających konfliktom interesów, co jest jak najbardziej właściwym i pożądanym kierunkiem. Nie określa jednak konsekwencji wystąpienia konfliktu interesów.

W dyrektywie MiFID II przewidziany jest znacznie bardziej rozbudowany zakres obowiązków, opisany w art. 24 ust. $2-14$ oraz art. $25^{24}$. Zmiany w dyrektywie dotyczą przede wszystkim tego, że

firmy inwestycyjne, które wystawiają instrumenty finansowe przeznaczone do sprzedaży klientom, zapewniają, aby te instrumenty finansowe były tworzone w sposób odpowiadający na potrzeby określonego rynku docelowego klientów końcowych w ramach danej kategorii klientów, aby strategia dystrybucji instrumentów finansowych była zgodna $\mathrm{z}$ określonym rynkiem docelowym oraz aby firma inwestycyjna podejmowała uzasadnione działania w celu zapewnienia dystrybucji produktu finansowego na określonym rynku docelowym ${ }^{25}$

oraz że

Wszystkie informacje, w tym publikacje handlowe, kierowane przez firmę inwestycyjną do klientów lub potencjalnych klientów muszą być rzetelne, wyraźne i niewprowadzające w błąd. Publikacje handlowe oznacza się wyraźnie jako publikacje handlowe ${ }^{26}$.

Dyrektywa uszczegóławia również wymogi co do oceny adekwatności i odpowiedniości świadczonych usług finansowych ${ }^{27}$, nakłada większy rygor na doradztwo inwestycyjne i doradztwo niezależne ${ }^{28}$, zakazuje wynagradzania czy oceny pracowników pracujących w firmach inwestycyjnych w sposób mogący narażać interesy klienta ${ }^{29}$, a także doprecyzowuje procedury z zakresu zarządzania produktem finansowym oraz jego nadzorem ${ }^{30}$.

Przedstawione przepisy zawarte w MiFID oraz MiFID II ,stanowią fundament standardu świadczenia usług firm inwestycyjnych wobec klientów"31, skupiając się na zasadach równego, uczciwego traktowania. Są podstawą do wyznaczenia kierunku, standardów oraz ukazują szczegółowy sposób, w jaki wykonywane powinny być obowiązki przez firmy inwestycyjne. Prawo unijne za pomocą dyrektywy MiFID doprowadza do ujednolicenia obowiązków zarządzających funduszami inwestycyjnymi w stosunku do inwestorów ${ }^{32}$. Europejski Urząd Nadzoru Giełd i Papierów Wartościowych (ESMA) opublikował zbiór wszystkich RTS-ów i ITS-ów, czyli aktów wykonawczych do systemu MiFID II/MiFIR, jako Technical standards under Directive 2004/39/EC (MiFID I), Directive 2014/65/EU (MiFID II) and Re-

24 Art. 25 ust. 2-14 dyrektywy MiFID II.

25 Art. 24 ust. 2 dyrektywy MiFID II.

26 Art. 24 ust. 3 dyrektywy MiFID II.

27 Art. 25 dyrektywy MiFID II.

28 Art. 24 ust. 4, 7 dyrektywy MiFID II.

29 Art. 24 ust. 10 dyrektywy MiFID II.

30 Art. 16 ust. 3 dyrektywy MiFID II.

31 Prawo instrumentów finansowych, red. M. Stec, „System Prawa Handlowego” t. 4, Warszawa 2016, s. 42.

32 Ibidem. 
gulation (EU) No 600/2014 (MiFIR) ${ }^{33}$. Ponadto wskazane regulacje uzupełniane są między innymi o wytyczne ESMA do podanych aktów prawnych.

Według KNF obowiązek transpozycji takich wytycznych do aktów prawa polskiego wynika z zapewnienia skuteczności ich przestrzegania. Dyrektywa MiFID II, oprócz wprowadzenia wielu nowych wymogów związanych ze świadczeniem usług inwestycyjnych, utrzymuje liczne rozwiązania i zasady prawne kluczowe dla świadczenia usług inwestycyjnych w UE, w tym podstawowe warunki udzielania zezwoleń i prowadzenia działalności dla firm inwestycyjnych oraz rynków regulowanych, a także towarzystw funduszy inwestycyjnych ${ }^{34}$.

Ochrona inwestorów jest określona jako nadrzędny cel oraz funkcja prawa na rynku kapitałowym. Podsumowując, należy skonstatować, że ustawodawca za pomocą ustalonych norm stara się wprowadzić ochronę inwestorów przed zagrożeniami, jakie mogą mieć miejsce na rynku kapitałowym. Dotyczą one w szczególności ${ }^{35}$ :

— możliwości, w której inwestor nie uzyska informacji niezbędnej do podjęcia decyzji inwestycyjnej;

- wystąpienia ryzyka stracenia środków finansowych;

— ryzyka, w którym zarządzający środkami dokonuje niewłaściwego zarządzania nimi, na przykład fundusze inwestycyjne;

- niebezpieczeństwa związanego z narzuceniem na inwestora niekorzystnych warunków umowy przez inne podmioty;

— możliwości wystąpienia monopolizacji rynku;

— zachwiania stabilności rynkowej.

W obliczu wymienionych problemów system ochrony inwestorów skonstruowano poprzez ${ }^{36}$ :

- wprowadzenie obowiązków informacyjnych uczestników wobec inwestorów i rynku, które obejmują pełną, rzetelną, uczciwą oraz w zakładającą ujawnienie w odpowiednim czasie informacji, które mają wpływ zarówno na ceny instrumentów finansowych, jak i ochronę ich interesów przez nadużyciami mogącymi wystąpić na rynku;

— rygor dotyczący zapobiegania oraz ochrony inwestorów wobec nadużyć występujących na rynku;

— reżim dotyczący nałożenia obowiązków na pośredników inwestycyjnych do uczciwego, rzetelnego oraz profesjonalnego działania w interesie klientów;

33 Technical standards under Directive 2004/39/EC (MiFID I), Directive 2014/65/EU (MiFID II) and Regulation (EU) No 600/2014 (MiFIR), http://mifid.pl/wp-content/uploads/2017/02/its-rts-overview-table_en.pdf(dostęp: 10.06.2018).

${ }^{34} \mathrm{KN} F$, Stanowisko Urzędu Komisji Nadzoru Finansowego $w$ sprawie stosowania $w$ Polsce Dyrektywy MiFID II od 3 stycznia 2018 r., https://www.knf.gov.pl/knf/pl/komponenty/img/Stanowisko_UKNF_ws_stosowania_MiFID_II_60535.pdf (dostęp: 1.06.2018).

35 A. Chłopecki, M. Dyl, Prawo rynku kapitałowego, wyd. 4, Warszawa 2015, s. 1-2; Prawo rynku kapitałowego, red. T. Sójka, Warszawa 2015, s. 1392.

36 Prawo rynku kapitałowego..., s. 1392. 
— edukowanie uczestników rynku z zakresu wiedzy finansowej na temat rynku kapitałowego oraz zasad bezpiecznego inwestowania;

- określenie wymogów dla podmiotów, które są częścią infrastruktury rynku, czyli emitentów, izb rozliczeniowych, agencji ratingowych, depozytów instrumentów finansowych, a także organów nadzoru;

- wprowadzenie systemów rekompensat oraz innych form ubezpieczeń czy gwarancji inwestorskich;

— nadzór nad rynkiem krajowym i zagranicznym oraz jego uczestnikami;

- wprowadzenie systemu uprawnień przyznawanych inwestorom, a przede wszystkim klientom firm inwestycyjnych, akcjonariuszom spółek publicznych oraz uczestnikom funduszy inwestycyjnych.

Poza wskazanymi regulacjami unijnymi można również wymienić inne rozwiązania, które mają między innymi przeciwdziałać nieuczciwym praktykom w zakresie konfliktu interesów, takie jak:

- Kodeks dobrej praktyki domów maklerskich,

- Ustawa z dnia 23 sierpnia 2007 roku o przeciwdziałaniu nieuczciwym praktykom rynkowym ${ }^{37}$,

- Ustawa z dnia 29 lipca 2005 roku o obrocie instrumentami finansowymi ${ }^{38}$.

Nadzór nad funkcjonowaniem rynku kapitałowego poprzez przywołane regulacje w dużym stopniu zapewnia bezpieczeństwo obrotu środkami inwestowanymi przez inwestorów. Pozwalają bowiem oddziaływać na rynek kapitałowy i ograniczać nieuczciwe działania pośredników, które na rynku kapitałowym mają znaczną przewagę w stosunku do inwestorów, szczególnie tych drobnych. Nie sposób jednak poprzez istniejące rozwiązania zapobiec wszelkim negatywnym zachowaniom na rynku kapitałowym. Dodatkowo pośrednicy mogą celowo wykorzystywać swoje przewagi, gdyż zdają sobie sprawę, że bardzo trudno wykazać osobie odpowiedzialnej za inwestowanie, że działała w złej wierze albo że przedkładała wyniki jednej transakcji nad drugą. Dlatego też istniejące regulacje mocno podkreślają działalność etyczną, wymaganą w szczególności od podmiotów mających większe uprawnienia.

Realia pokazują jednak, iż występujące normy prawne nie są w stanie ustrzec inwestorów przed negatywnymi konsekwencjami występowania konfliktu interesów. Potwierdzeniem mogą być wyniki badań przeprowadzonych na Uniwersytecie w Michigan. Przeanalizowano kilkadziesiąt lat działalności instytucji finansowych oraz wpływ potencjalnych „dziur” w chińskich murach na wyniki portfeli osób mających dostęp do informacji poufnych. Okazało się, że różnica między wynikami inwestycyjnymi była znacząca z dużą korzystną różnicą po stronie osób z większą wiedzą ${ }^{39}$, co oznacza, że przewartościowane walory były

37 Dz.U. z 2007 r. Nr 171, poz. 1206.

38 Dz.U. z 2005 r. Nr 183, poz. 1538.

39 B. DeGroat, Chinese walls' fail to curb conflicts of interest in securities firms, ,The University Record Online. University of Michigan News Service", uhttp://www.ur.umich.edu/0203/ Feb17_03/07.shtml (dostęp: 2.09.2017). 
zazwyczaj sprzedawane szerokiej rzeszy inwestorów z mniejszą wiedzą w czasie, w którym pozbywa się ich firma rekomendująca, na przykład własnym klientom, na których rzecz świadczono usługę zarządzania aktywami.

W szczególności w odniesieniu do umów o zarządzanie aktywami działania pośrednika uwikłanego w konflikt interesów mogą być przyczyną negatywnych efektów prowadzonych $\mathrm{w}$ imieniu inwestora inwestycji kapitałowych. Umowa o zarządzanie aktywami zobowiązuje pośrednika do profesjonalnego działania, podejmowania działań mających na celu optymalizowanie wyników uzyskiwanych z zarządzanego portfela instrumentów finansowych. Niestety zarządzanie aktywami może przerodzić się $\mathrm{w}$ administrowanie portfelem i kupowanie do niego walorów powiązanych z pośrednikiem. Do tego często dochodzi pozostawianie tych walorów na koncie inwestora, niedokonywanie aktywnych działań z zakresu kupna i sprzedaży, niereagowanie na spadki, ignorowanie jakichkolwiek alertów sprzedażowych niczym sztucznego utrzymywania kursu walorów powiązanych kosztem swoich klientów. Ewentualna wyprzedaż walorów powiązanych w trendzie spadkowym, w szczególności na mało płynnym rynku, mogłaby doprowadzić do istotnego spadku wartości. Prawidłowość ta może wpływać na zachowanie domu maklerskiego i dlatego też należy podkreślić, że pośrednik zarządzając aktywami, nie powinien angażować się w liczne walory powiązane, gdyż jest to ryzykowne dla inwestora ze względu na wskazany konflikt interesów i możliwość podejmowania decyzji niezgodnych z interesem inwestora.

Możliwość dokonywania zakupów walorów powiązanych przez pośrednika w imieniu swoich klientów lub nachalnego rekomendowania tego typu walorów pozwala również pośrednikom prowadzić ukrytą manipulację rynkiem. Pośrednik, mając wpływ na zakup określonych walorów, w szczególności powiązanych, i angażując środki swoich klientów, osiąga efekt skali, który może być zauważalny na rynku, zwłaszcza w odniesieniu do mniejszych podmiotów, i kreować impuls zakupowy u innych uczestników rynku kapitałowego, którzy zauważając ruch na określonych walorach, mogą się nimi zainteresować, aczkolwiek należy pamiętać, że ruch ten nie będzie rynkowy, nie będzie przejawem zainteresowania większej liczby inwestorów, a jedynie jednego pośrednika. Rynek widzi zachowania inwestorów, jednak za tymi zachowaniami może stać jeden pośrednik.

Przedstawione rozważania w zakresie konsekwencji konfliktu interesów potwierdzają różne badania. Mało czysta sytuacja może również uzasadniać straty na dokonywanych inwestycjach oraz sztuczne zawyżanie ceny spółek IPO ${ }^{40}$. Roni Michaely i Kent Womack wykazali, że konflikty interesów rzeczywiście miały konsekwencje dla wyceny aktywów, ponieważ zniekształcony optymizm wywodzący się z tych konfliktów nie został w pełni uznany przez inwestorów ${ }^{41}$.

40 J. Lizińska, L. Czapiewski, Determinanty underpricingu w Polsce $i$ na innych wybranych rynkach wschodzacych, [w:] Efektywność — rozważania nad istota i pomiarem, red. T. Dudycz, „Prace Naukowe UE we Wrocławiu” 386, 2015, s. 112-125.

41 R. Michaely, K. Womack, Conflict of interest and the credibility of underwriter analyst recommendations, „The Review of Financial Studies” 12, 1999, nr 4, s. 653-686; L. Madurei, Conflicts 
Michaely i Womack, a także Hsiou-wei Lin i Maureen McNichols ${ }^{42}$ twierdzą, że domy maklerskie mają tendencję do stronnictwa w swoich zaleceniach dla firm, z którymi mają kontrybucje. Ponadto badanie bankowców inwestycyjnych i menedżerów inwestycyjnych prowadzone przez Michaely i Womacka sugeruje, że wystąpienie konfliktu interesów między bankiem inwestycyjnym a działami badawczymi jest bardziej prawdopodobne niż niewystąpienie takiego konfliktu ${ }^{43}$. Autorzy raportu opublikowanego w „Wall Street Journal"44 potwierdzają podstawowe statystyki badań i stwierdzają, że czołowe firmy zajmujące się bezpieczeństwem konsekwentnie dają wyższe oceny swoim klientom.

Z konfliktem interesów wiąże się również problem dotyczący sposobu, w jaki eksperci czy analitycy finansowi usprawiedliwiają błędy swoich prognoz ${ }^{45}$. Inwestorzy korzystający z rad analityków są bardzo niezadowoleni, gdy ich prognozy okazują się niedokładne, co jest naturalne, jako że prowadzi to do utraty oczekiwanych korzyści ekonomicznych. Z punktu widzenia analityków takich sytuacji należy unikać, gdyż w konsekwencji mogą prowadzić do utraty klientów. Aby się przed tym uchronić, jak mówią Tadeusz Tyszka i Piotr Zielonka, analitycy finansowi wykazują nadwrażliwość na punkcie swojej reputacji i są bardziej wprawieni w znajdowaniu usprawiedliwień swoich nietrafnych prognoz ${ }^{46}$. Dlatego też analitycy są $\mathrm{w}$ stanie znaleźć różnorodne przyczyny niepowodzenia inwestycji kapitałowych, ukrywając ewentualną prawdziwą przyczynę, jaką może być konflikt interesów.

\section{Wnioski - propozycja regulacji z zakresu konfliktu interesów}

Zachowanie pośredników na rynku kapitałowym w kontekście nieprzeciwdziałających negatywnym aspektom konfliktu interesów regulacjom na rynku kapitałowym uzasadnia poszukiwanie nowych rozwiązań, które mogą skuteczniej odstraszyć pośredników od wykorzystywania swojej pozycji i czerpania korzyści $\mathrm{z}$ doprowadzania do konfliktu interesów. Istniejące regulacje praktycznie w żadnym stopniu nie są $\mathrm{w}$ stanie zrekompensować inwestorowi poniesionych strat,

of interest, regulations, and stock recommendations, The Wharton School University of Pennsylvania, październik 2004, s. 1, http://finance.wharton.upenn.edu/department/Seminar/2004Fall/MicroFall2004/micro-madureira-102804.pdf (dostęp: 2.09.2017).

$42 \mathrm{H}$. Lin, M. McNichols, Underwriting relationships, analysts' earnings forecasts and investment recommendations, „Journal of Accounting and Economics” 25, 1998, s. 101-127.

43 R. Michaely, K. Womack, op. cit.

44 Analitycy umieszczają swoich klientów na pierwszym miejscu, raport, „Wall Street Journal” 7.04.2003, s. C1.

45 P. Zielonka, Giełda i psychologia. Behawioralne aspekty inwestowania na rynku papierów wartościowych, Warszawa 2015, s. 153.

46 T. Tyszka, P. Zielonka, Expert judgments: Financial analysts versus weather forecaster, „The Journal of Psychology and Financial Markets” 2002, nr 3 (3), s. 152-160. 
które mogą być następstwem wystąpienia konfliktu interesów. W efekcie inwestor musi decydować się na wejście na drogę sądową i dochodzić od pośrednika zadośćuczynienia za straty poniesione w wyniku niekorzystnego zarządzania lub doradztwa obarczonego konfliktem interesów. W europejskich realiach sądowych wiąże się to $\mathrm{z}$ długotrwałym i bardzo trudnym pod względem dowodowym procesem, który polega przede wszystkim na dochodzeniu racji, a w szczególności na wykazaniu związku przyczynowo-skutkowego między decyzjami podjętymi przez pośrednika obarczonymi konfliktem interesów a wynikiem zarządzanego portfela inwestycyjnego. Inwestor musi wykazać, że poniesiona przez niego w wyniku działań pośrednika strata (łac. damnum emergens) z zainwestowanych środków przekracza granice zwykłego ryzyka gospodarczego i jest wynikiem niezachowania przez pozwanego należytej staranności przy świadczeniu usług maklerskich mierzonej w tym wypadku przy zastosowaniu podwyższonego miernika wynikającego z zawodowego wykonywania działalności (art. 355 § 2 k.c.) i dochodzić na podstawie art. 471 k.c. odszkodowania z tytułu nienależytego wykonania umowy przez pośrednika, który stanie się pozwanym, w zakresie damnum emergens. Do przesłanek wskazanej odpowiedzialności dłużnika (zwanej odpowiedzialnością kontraktową) należy powstanie szkody majątkowej po stronie wierzyciela, szkoda ta musi być jednak spowodowana niewykonaniem lub nienależytym wykonaniem zobowiązania przez dłużnika, a nadto konieczne jest wykazanie pomiędzy powstałą szkodą a jej niewykonaniem lub nienależytym wykonaniem adekwatnego związku przyczynowego (art. $361 \S$ k.c.). Należy też zastrzec, że w świetle art. 471 k.c. spełnienie wskazanych przesłanek nie przesądza jeszcze o powstaniu na rzecz wierzyciela roszczenia o naprawienie szkody. Przepis ten wymaga bowiem, aby niewykonanie lub nienależyte wykonanie zobowiązania było następstwem okoliczności, za które dłużnik ponosi odpowiedzialność. W doktrynie przyjmuje się, że unormowanie zawarte $\mathrm{w}$ art. $361 \S 1$ k.c. opiera się na założeniach teorii adekwatnego związku przyczynowego (przyczynowości adekwatnej) w wersji obiektywnej, zwanego też „normalnym związkiem przyczynowym". Teoria ta zakłada, że związek przyczynowy zachodzi tylko wtedy, gdy w grupie wszystkich przyczyn i skutków mamy do czynienia jedynie z takimi przyczynami, które normalnie powodują określone skutki. Nie wystarczy więc stwierdzić istnienie związku przyczynowego jako takiego, lecz należy dowieść, że chodzi o następstwa normalne (a nie niezwykłe, nadzwyczajne). Przy ocenie normalności następstw trzeba $\mathrm{w}$ dodatku odwoływać się do reguł obiektywnie ustalonych, a nie wiedzy o związkach przyczynowych osoby odpowiedzialnej ${ }^{47}$.

${ }^{47}$ Kodeks cywilny. Komentarz, red. J. Gudowski, t. 4-5. Zobowiazania. Czesść szczegółowa, Warszawa 2017, s. 58; Z. Radwański, A. Olejniczak, [w:] Kodeks cywilny. Komentarz, red. J. Gudowski, t. 3. Zobowiązania - część ogólna, Warszawa 2016, s. 81; A. Rembieliński, [w:] Kodeks cywilny z komentarzem, red. Z. Gordon, t. 1, Warszawa 1989, s. 267; K. Zagrobelny, [w:] Kodeks cywilny. Komentarz, red. E. Gniewek, P. Machnikowski, wyd. 8, Warszawa 2017. 
Specyfika inwestycji kapitałowych wprowadza trudności dowodowe, gdyż podjęcie jakiejkolwiek decyzji inwestycyjnej zawsze narażone jest na stratę. W efekcie pośrednik zawsze będzie podnosił ten zarzut i bronił każdej swojej decyzji w zakresie kupna i sprzedaży, niezależnie od poziomu straty, do jakiego ona doprowadziła. Wydaje się więc uzasadnione, aby w prawodawstwie wprowadzić zasadę, że pośrednik odpowiada za wszystkie nieuprawnione inwestycje, W szczególności za te związane z konfliktem interesów, o ile inwestor nie wyrazi na nie zgody. Obecnie pośrednik, który w imieniu inwestora będzie inwestował $\mathrm{w}$ walory powiązane, nawet gdy jest to nieuprawnione zawartą umową pomiędzy pośrednikiem a inwestorem i inwestor nie wyrazi zgody na takie inwestycje, nie ponosi automatycznie żadnych konsekwencji za naruszenie zapisów umownych łączących strony. Inwestor musi bowiem udowadniać pojawienie się nieprawidłowości $\mathrm{w}$ działaniach pośrednika, jednak samo stwierdzenie naruszenia umowy przez dom maklerski nie uprawnia inwestora do odszkodowania, gdyż należy wykazać związek przyczynowo-skutkowy, co na rynku kapitałowym ze względu na jego specyfikę jest bardzo trudne. Dodatkowo nie wystarczy wykazać, że pośrednik zawarł nieuprawnione transakcje zakupu w walory powiązane z nim, naruszając tym samym zakaz doprowadzania do konfliktu interesów, i pokazać na liczbach, że na tych inwestycjach inwestor poniósł stratę. Sądy niestety rozpatrują sprawę w szerszym kontekście, biorąc pod uwagę przykładowo, jaka była sytuacja na rynku, czy inwestując $\mathrm{w}$ inne walory, nie poniesiono by podobnych strat. Należy przekonać sąd, że na pewno konflikt interesu miał związek z poniesieniem przez inwestora straty. Sądy niestety nie traktują takich sytuacji zero-jedynkowo, a powinny, w myśl zasady ,pośredniku, zainwestowałeś w walory powiązane, wystąpił konflikt interesu, w związku z tym ponosisz odpowiedzialność za wszystkie straty, które inwestor poniósł”. Podnosi się, aby praktyka sądowa w zakresie dochodzenia odszkodowania na podstawie art. 471 k.c. uznawała, iż złamanie treści umowy łączącej pośrednika z inwestorem, między innymi w zakresie nieuprawnionego doprowadzenia do konfliktu interesów, była traktowana jako nienależyte wykonanie umowy bez wymagania wykazywania związku przyczynowo-skutkowego.

\section{Bibliografia}

\section{Dokumenty prawne}

Directive 2013/36/EU of the European Parliment and the Council of 26 June 2013 on access to the activity of credit institutions and the prudential supervision of credit institutions and investment firms, amending Directive 2002/87/EC and repealing Directives 2006/48/EC and 2006/49/EC, Official Journal of the European Union L 176/338 from 27.06.2013.

Dyrektywa MiFID: Dyrektywa 2004/39/WE Parlamentu Europejskiego i Rady z dnia 21 kwietnia 2004 roku w sprawie rynków instrumentów finansowych zmieniająca dyrektywę Rady 85/611/ EWG i 93/6/EWG i dyrektywę 2000/12/WE Parlamentu Europejskiego i Rady oraz uchylająca 
dyrektywę Rady 93/22/EWG, Dz.U. UE L145 z 30.04.2004, http://eur-lex.europa.eu/legal-content/PL/TXT/?uri=CELEX:02004L0039-20110104.

Dyrektywa MiFID II: Dyrektywa Parlamentu Europejskiego i Rady 2014/65/UE z dnia 15 maja 2014 roku w sprawie rynków instrumentów finansowych oraz zmieniająca dyrektywę 2002/92/ WE i dyrektywę 2011/61/UE, Dz.Urz. UE L 173/349 z 12.06.2014, https://eur-lex.europa.eu/ legal-content/PL/TXT/?uri=celex\%3A32014R0600.

Rozporządzenie Parlamentu Europejskiego i Rady (UE) nr 596/2014 z dnia 16 kwietnia 2014 roku w sprawie nadużyć na rynku (rozporządzenie w sprawie nadużyć na rynku) oraz uchylające dyrektywę 2003/6/WE Parlamentu Europejskiego i Rady i dyrektywy Komisji 2003/124/WE, 2003/125/WE i 2004/72/WE, Dz.U. UE L 173/1 z 12.06.2014.

Rozporządzenie Parlamentu Europejskiego i Rady (UE) nr 600/2014 z dnia 15 maja 2014 roku w sprawie rynków instrumentów finansowych oraz zmieniające rozporządzenie (EU) $\mathrm{nr}$ 648/2012, Dz.Urz. UE OJ L 173 z 12.06.2014, s. 84-148.

Standard ogólnych zasad zarządzania konfliktem interesów udostępniany klientom przed zawarciem umowy - Rozporządzenie Ministra Finansów z dnia 30 maja 2018 roku w sprawie trybu i warunków postępowania firm inwestycyjnych, banków, o których mowa w art. 70 ust 2 ustawy o obrocie instrumentami finansowymi oraz banków powierniczych, Dz.U. z 2018 r. poz. 1112.

Ustawa z dnia 27 maja 2004 roku o funduszach inwestycyjnych i zarządzaniu alternatywnymi funduszami inwestycyjnymi, Dz.U. z 2004 r. Nr 146, poz. 1546.

Ustawa z dnia 29 lipca 2005 roku o obrocie instrumentami finansowymi, Dz.U. z 2005 r. Nr 183, poz. 1538.

Ustawa z dnia 23 sierpnia 2007 roku o przeciwdziałaniu nieuczciwym praktykom rynkowym, Dz.U. z 2007 r. Nr 171, poz. 1206.

Ustawa z dnia 4 września 2008 roku o zmianie ustawy o obrocie instrumentami finansowymi oraz niektórych innych ustaw, Dz.U. z 2009 r. Nr 165, poz. 1316.

\section{Źródła}

Analitycy umieszczaja swoich klientów na pierwszym miejscu, raport, „Wall Street Journal” 7.04.2003.

KNF, Stanowisko Urzędu Komisji Nadzoru Finansowego w sprawie stosowania w Polsce Dyrektywy MiFID II od 3 stycznia 2018 r., https:/www.knf.gov.pl/knf/pl/komponenty/img/Stanowisko_UKNF_ws_stosowania_MiFID_II_60535.pdf (dostęp: 1.06.2018).

\section{Literatura}

Chłopecki A., Dyl M., Prawo rynku kapitałowego, wyd. 4, Warszawa 2015.

Cohen J., Holder L., Pant L., Sharp D.J., The effects of perceived fairness on opportunistic behavior, „Contemporary Accounting Research” 2007, nr 24 (4).

Cornell B., Roll R., Strategies for pairwise competitions in market and organizations, „Bell Journal of Economics" 1981, nr 12 (1).

Czekaj J., Woś M., Żarnowski J., Efektywność giełdowego rynku akcji w Polsce, Warszawa 2001.

Dybowski T., System prawa cywilnego, [w:] System prawa cywilnego, t. 3, cz. 1. Prawo zobowiazań - część ogólna, red. Z. Radwański, Wrocław 1981.

Friend I., Brown F., Herman E., Vickers D., A Study of Mutual Funds, Washington 1962.

Gillder G., Afera z wykorzystaniem informacji poufnych, [w:] Reguły giełdy, red. J.F. Mauldin, Gliwice 2006.

Góralczyk jun. W., Tajemnica bankowa, [w:] Prawo informacji, prawo do informowania, red. W. Góralczyk jun., Warszawa 2006.

Jaffe J., Special information and insider trading, „Journal of Business” 1974, nr 47. 
Kodeks cywilny. Komentarz, red. J. Gudowski, t. 4-5. Zobowiązania. Czesść szczegółowa, Warszawa 2017.

Lin H., McNichols M., Underwriting relationships, analysts' earnings forecasts and investment recommendations, „Journal of Accounting and Economics” 25, 1998.

Lizińska J., Czapiewski L., Determinanty underpricingu w Polsce i na innych wybranych rynkach wschodzacych, [w:] Efektywność - rozważania nad istota i pomiarem, red. T. Dudycz, „Prace Naukowe UE we Wrocławiu" 386, Wrocław 2015.

Michaely R., Womack K., Conflict of interest and the credibility of underwriter analyst recommendations, „The Review of Financial Studies” 12, 1999, nr 4.

Mikita M., Rynek finansowy Unii Europejskiej - wyzwania, „Studia BAS” 2012, nr 3 (31).

Prawo instrumentów finansowych, red. M. Stec, „System Prawa Handlowego”, t. 4, Warszawa 2016.

Prawo rynku kapitatowego, red. T. Sójka, Warszawa 2015.

Radwański Z., Olejniczak A., [w:] Kodeks cywilny. Komentarz, red. J. Gudowski, t. 3. Zobowiąania - część ogólna, Warszawa 2016.

Rembieliński A., [w:] Kodeks cywilny z komentarzem, red. Z. Gordon, t. 1, Warszawa 1989.

Ślepaczuk R., Anomalie rynku kapitałowego w świetle hipotezy efektywności rynku, „e-Finanse: Finansowy Kwartalnik Internetowy" 2006, nr 6.

Tyszka T., Zielonka P., Expert judgments: Financial analysts versus weather forecaster, „The Journal of Psychology and Financial Markets" 2002, nr 3 (3).

Wasilewski M., Juszczyk M., Znaczenie czynników behawioralnych w podejmowaniu decyzji inwestycyjnych na rynku kapitałowym, ,Zeszyty Naukowe Szkoły Głównej Gospodarstwa Wiejskiego. Ekonomika i Organizacja Gospodarki Żywnościowej” 2016, nr 113.

Zielonka P., Giełda i psychologia. Behawioralne aspekty inwestowania na rynku papierów wartościowych, Warszawa 2015.

Zagrobelny K., [w:] Kodeks cywilny. Komentarz, red. E. Gniewek, P. Machnikowski, wyd. 8, Warszawa 2017.

\section{Źródła internetowe}

DeGroat B., Chinese walls'fail to curb conflicts of interest in securities firms, „The University Record OnLine. University of Michigan News Service", http://www.ur.umich.edu/0203/Feb17_03/07. shtml.

European Securities and Markets Authority, MiFID II, https://www.esma.europa.eu/policy-rules/ mifid-ii-and-mifir\#title-paragrah-2.

Governor Draghi's speech at the Integrated and Stable Financial Markets Conference, 2 maja 2011 roku, Bruksela, http://ec.europa.eu.

Izba Domów Maklerskich, Kodeks dobrej praktyki domów maklerskich, https://idm.com.pl/images/ regulacje/Kodeks_dobrej_praktyki_domow_maklerskich.pdf.

Madurei L., Conflicts of interest, regulations, and stock recommendations, The Wharton School University of Pennsylvania, październik 2004, http://finance.wharton.upenn.edu/department/ Seminar/2004Fall/MicroFall2004/micro-madureira-102804.pdf.

Technical standards under Directive 2004/39/EC (MiFID I), Directive 2014/65/EU (MiFID II) and Regulation (EU) No 600/2014 (MiFIR), http://mifid.pl/wp-content/uploads/2017/02/its-rtsoverview-table_en.pdf. 